\title{
THE PROFILE OF THE FOREIGN TOURISTS VISITING CLUJ-NAPOCA
}

\section{LOREDANA MARIA TALPOȘ1, CRISTINA BOLOG²}

\begin{abstract}
The Profile of the Foreign Tourists Visiting Cluj-Napoca. The purpose of this study is to identify and analyze the profile of the foreign tourists visiting Cluj-Napoca. Knowledge regarding the features of this type of tourists and updated information are important to develop the tourism area and useful for the tourism services providers. The destination is registering annual growth of the number of foreign tourists and this study is intended to be the starting point of a wider research aiming to discover and analyze the features of the foreign tourists visiting the city of Cluj-Napoca. 200 surveys were applied to foreign tourists in Cluj-Napoca, in May and June 2017, when the city applied for the title of European Capital of Culture and, to have a broader image, we analyzed a previous partially similar research realized in 2015 , when the city was European Youth Capital. The research reveals information regarding the geographical features, the socio-demographic attributes and behavioural characteristics of the foreign tourists who visit a place that, nowadays, is increasing in popularity - the city of Cluj-Napoca.
\end{abstract}

Keywords: tourist profile, incoming tourism, survey, Cluj-Napoca, Romania.

\section{INTRODUCTION}

Cluj-Napoca is a very dynamic city (Benedek, 2010) and a travel destination located in Romania, in the North-Western part of the country in the historical province of Transylvania (Benedek, 2006), being its largest and the most complex city. It is situated in the North-West Development Region of Romania and is the seat of Cluj County. The settlement has reinforced the tertiary functions after the year 1989 (Benedek, 2006) and it is a destination that records annual increases in the number of total and foreign tourists.

1 "Babeș-Bolyai" University, Faculty of Geography, Doctoral School of Geography, 5-7 Clinicilor Street, Cluj-Napoca, Romania, e-mail: lore.talpos@gmail.com

2 "Babeș-Bolyai" University, Faculty of Geography, 5-7 Clinicilor Street, Cluj-Napoca, Romania, e-mail: cristina.bolog@ubbcluj.ro 
Related to the geographical aspects, Cluj-Napoca was built on the sides of Somessul Mic river in the area of connection of three landscapes: in the west and north the Hills of Cluj, in the south Feleacului Hills and in the east the Transylvanian Plain (Benedek, 2010).

Also, this settlement has an ancient history. In the Antiquity there was a Dacian settlement called Napuca and, afterwards the Roman one, named Napoca. In the Middle Ages, there appeared the Cluj settlement that obtained the status of a city in 1316 and was allowed to build walls around it in 1405, fact that led to the development of the inner city of Cluj historical district. In the Middle Ages, Cluj was called the "treasure city" due to the existence of its numerous tradesmen and craftsmen (Benedek, 2006). The fortress of Cluj was remodeled in the Baroque architectural style in the $18^{\text {th }}$ century, when Transylvania was part of the Austrian Empire and it acquired other cultural landmarks during the Austro-Hungarian period. Also, in the $20^{\text {th }}$ century, after the Great Union of 1918, the city was part of Romania, the establishment of the communist regime followed after the Second World War and the transition to democracy after 1989 (http://www.clujnapoca2021.ro/proiecte/aplicatiecluj-napoca-2021.html).

Cluj-Napoca was European Youth Capital in the year 2015 and reached the final for the title of European Capital of Culture 2021. Also, this city has a series of tourism urban symbols such as: the tradition of urban history that is of European value, the multiculturalism doubled by pluriconfesionalism, the eventful and punctual history that is transmitted through stories, myths and legends, the educational and academic continuity, places and more recent experiences, evidence of the dynamics of ecology and creativity initiated and maintained by locals and young people, the multitude of events, the atmosphere of a dynamic, young and cultural city with business, work and leisure opportunities (Bolog and Mathe, 2015).

Tourism in Romania, in the county of Cluj and also in the city of ClujNapoca is experiencing continuous growth and development.

Related to the tourism in Romania, there can be mentioned that it records a continuous development in the number of total tourists and, also, of the incoming tourists. In the last three years, for which statistical data are available, the number of tourist arrivals is as follows: in the year 2015 $9,921,874$ tourist arrivals (2,239,978 foreign tourists), in $2016-11,002,522$ tourist arrivals $(2,480,824$ foreign tourists) and in $2017-12,143,346$ tourist arrivals $(2,760,080$ foreign tourists) (INS, 2018).

Compressing the analysed territory, one may mention that also the number of tourist arrivals has increased for the Cluj County (whose capital is the city of Cluj-Napoca): 2015 - 428,812 tourist arrivals, 2016 - 498,465 tourist arrivals and in $2017-633,569$ tourist arrivals (INS, 2018). 
Also, reaching the territory for which the research was conducted, it should be mentioned that Cluj-Napoca also registers higher values every year: 319,220 tourist arrivals in 2015, 371,505 tourist arrivals in 2016 and in 2017 the number of tourist arrivals was 470,727. Also, the year 2016 was the first when the number of tourist arrivals was larger than the number of the citizens of ClujNapoca and, according to the same source, the Romania' National Institute of Statistics, $20 \%$ from the tourists that visited the city in the period between the $1^{\text {st }}$ of January 2016 and the $31^{\text {st }}$ of October 2016 were foreigners (INS, 2018).

The main purpose of this study is to identify and analyse the profile of the foreign tourists who visit Cluj-Napoca. It is divided into smaller components aiming to discover: the geographical features, the socio-demographic attributes of the tourists, their main motivation for traveling, the tourism circulation and the types of tourism packages and services chosen. It is intended to be the starting point of a wider research on this topic.

This subject was chosen due to the fact that knowledge regarding the features of foreign tourists and updated information are important to develop the tourism area and useful for the tourism services providers. Also, ClujNapoca is a destination registering an annual growth of the number of both the total number of tourist arrivals and the number of arrivals of foreign tourists.

Although it is an actual topic, approached predominantly in the last years, the papers on this topic are insufficient. Thus, we considered necessary a new study regarding the features of the foreign tourists who visit Cluj-Napoca, able to offer, as novelty elements, an actual image of the features of these tourists.

Tourism is a socio-economic phenomenon which is growing continuously and is created by the human need to recreate, know and recover physically and mentally, in a solicitant present, but with higher material possibilities for most of the people (Cocean and Dezsi, 2009). The United Nations classified tourism in: domestic, inbound and outbound tourism (Gabriela Stănciulescu and Olimpia State, 2013). Also, an essential element of the tourism industry is the person who realizes this act and, due to the fact that the international tourism is developing constantly, the traveler in another country is a popular topic for discussion. According to the World Tourism Organisation, the foreign tourists are persons who travel in a different country and stay at least 24 hours, the one who spends less than 24 hours being called "excursionist" (Păcurar, 2009).

Nowadays, the marketers use tourist segmentation in order to recognize the target groups and to understand their features, needs and priorities (Kuo et al, 2012; cited by Priporas et al, 2015).

According to McMillan Dictionary, the profile is a description of a person, group or organization for a better knowledge and the Oxford Dictionary states that it includes any type of information (behavioural, psychological or other type) able to offer information and to include a person in a typology or 
group (Iuliana Pop, 2013). Also, the profile of a tourism consumer consists of the geographical, demographic and behavioural features. (Othman and Jamal, 2011, cited by Iuliana Pop, 2013).

Research was performed about the profile of people practicing different types of tourism or approaching different geographical, demographic or behavioural features.

Research focused, for example, on the young tourists - using the push and pull factors (Prayag et al, 2015) or the senior tourists' profile - identifying subgroups (Pinheiro Melo Borges Tiago Maria Teresa et. al, 2016) motivation and perceptions (Lopez-Guzman, et al 2014).

Also, there were investigations related to the profile of the people who practice different types of tourism. For cultural tourism, profiles of tourists practicing this type of tourism were created, according to demographic and socio-economic features (Kim et al, 2006) and other studies analysed the features of people who attend cultural festivals - profiling tourists based on demographic features and motivations (Chang Janet, 2006). The profile of tourists practicing health (dental) tourism was analysed, focusing on demographic features, motivation and satisfaction (Jaapar et. al., 2017). Also, visiting friends and relatives has been approached by studying the heterogeneity of people practicing it in an urban destination and focusing on: travel concerns, trip planning, experience at the destination and after-travel behaviour (Svetlana Stepchenkova, 2015). Regarding student travel, the tourists were grouped by travel motivations (Marques Catarina et al, 2018) and, also, due to the fact that business travel is a popular topic for discussion, one analysed the features of the tourists practicing it and in which way the conventional tourism is present in the experience of the professional visitors (der Hoed and Russo, 2016).

Becker et al (2017) consider that demographic characteristics consist of aspects such as: age, gender, life cycle, civil status, type of job or home and, also, for the profile of the tourist, information was obtained about: the purpose of the visit, the visited destination, spending, activities realized, transportation or accommodation, length of stay, travel partners, the reservation facilities used, the information sources (Elisa Becker et al, 2017). Also, to identify the profiles of tourists, Lourdes Molera and Isabel Pilar Albaladejo assessed information regarding: age, gender, position in family, work status, income, level of education, place of residence, type of travel, area chosen, daily expenditure per person, size and composition of travel group, frequency of travels in terms of rural tourism, awareness of the destination, preferences for activities and type of accommodation (Lourdes Molera and Isabel Pilar Albaladejo, 2007) while Janet Chang based her study upon the demographic characteristics (gender, age, civil status, education occupation, residence) and motives (Janet Chang, 2006). 
Regarding the destination chosen for the actual research, Cluj-Napoca, we carried out a research about the foreign tourists who were visiting the city in the year 2015, when it had the title of European Youth Capital. 171 surveys have been applied to foreign tourists in Cluj-Napoca in June-July 2015, gathering information regarding the motivation, the tourist circulation and services (Toader et al, 2015).

Thus, in order to create a more complex image regarding the foreign tourists who visit Cluj-Napoca, for our research from the year 2017, the year when the city applied for the title of European Capital of Culture, hereafter called "the present research", we used and analysed also the information from that the study conducted in Cluj-Napoca in 2015, hereafter referred to as "the previous research".

The present research is aiming to offer relevant and actual answers to the questions "Who", "Why", "How" regarding foreign tourists traveling to ClujNapoca. "Who" - refers to the geographical and socio-demographic features, "Why" - related to the motivations and "How" - referring to behavioural characteristics such as those about their travel circulation and tourism packages and services chosen. In order to realize the study, we formulated the following questions that are, also, the secondary objectives of the study:

Q1.What are the geographical features of the tourists?

Q2.What are the socio-demographic features of the tourists?

Q3.What are their motivations for traveling?

Q4. What are the features related to their tourism circulation?

Q5 What types of tourism packages and services do they choose?

\section{MATERIALS AND METHODS}

The present research consists of: bibliographical study - by consulting specialized literature related to the chosen topic, the survey method by applying the questionnaire, data processing and graphics making use of Microsoft Excel and, also, the map has been realized using the ArcView 3.2 software.

Field trips were made in the places most frequented by foreign tourists - the historical center of Cluj-Napoca, the "Alexandru Borza" Botanical Garden, Simion Bărnuţiu Central Park. In this research, 200 questionnaires were applied to foreign tourists in Cluj-Napoca. Data were collected in the period May the $1^{\text {st }}$ - June the $7^{\text {th }}, 2017$. 
The survey calendar was as follows: March 25th - April $6^{\text {th }}$ - designing the questionnaire, April $7^{\text {th }}$ - April $14^{\text {th }}$ - conducting pilot tests for the application of the questionnaire, April $25^{\text {th }}-30^{\text {th }}$ finalizing the questionnaire, May $1^{\text {st }}$ June $7^{\text {th }}$ collecting the necessary data from the field by applying the questionnaire and June $7^{\text {th }}$ - June $12^{\text {th }}$ - data processing and realising the graphics.

\section{RESULTS AND DISCUSSIONS}

Regarding the geographical features of the foreign tourists in the present research, we obtained information related to the home country and the type of environment - urban or rural. It resulted that the tourists come from a wide range of countries, the top five emitting countries being: UK, Germany, USA, France and Hungary and over three quarters $(83.50 \%)$ of the respondents live in urban areas.

In terms of the socio-demographic features of tourists, one notices that genders have similar weights: $51.5 \%$ of the tourists are female and $48.5 \%$ male. Also, more than one half of tourists (53\%) belong to the 26-54 years age group and a bit more than one third of the respondents are 18-25 years old.

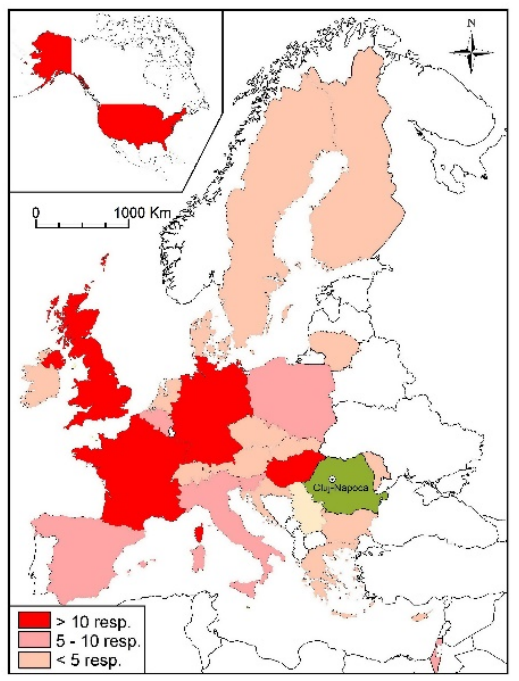

Fig. 1. The countries of residence of the foreign tourists
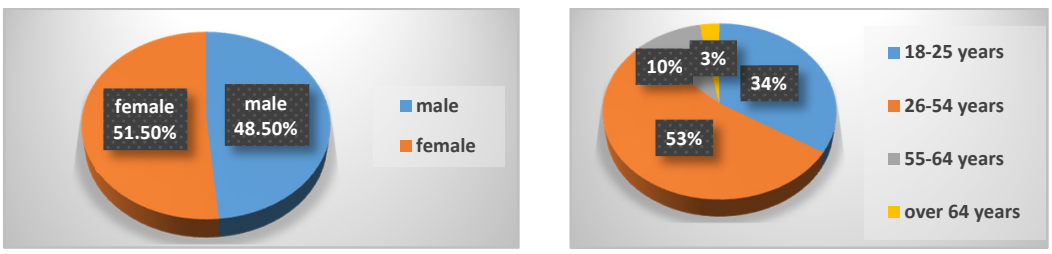

Fig. 2. Gender (left); b) Age groups (right)

In the most cases, the foreign tourists visiting Cluj-Napoca are unmarried (62\%) and one third of the respondents (33\%) are married.

Regarding the family members, most of the tourists live alone $(30 \%)$ or with another person (24\%) and there are no children in the family. 
Related to education, most of the tourists, approximately three quarters, have university studies (76\%), and according to the professional situation, they are professionally active and the net monthly family income is of less than 2999 euro.
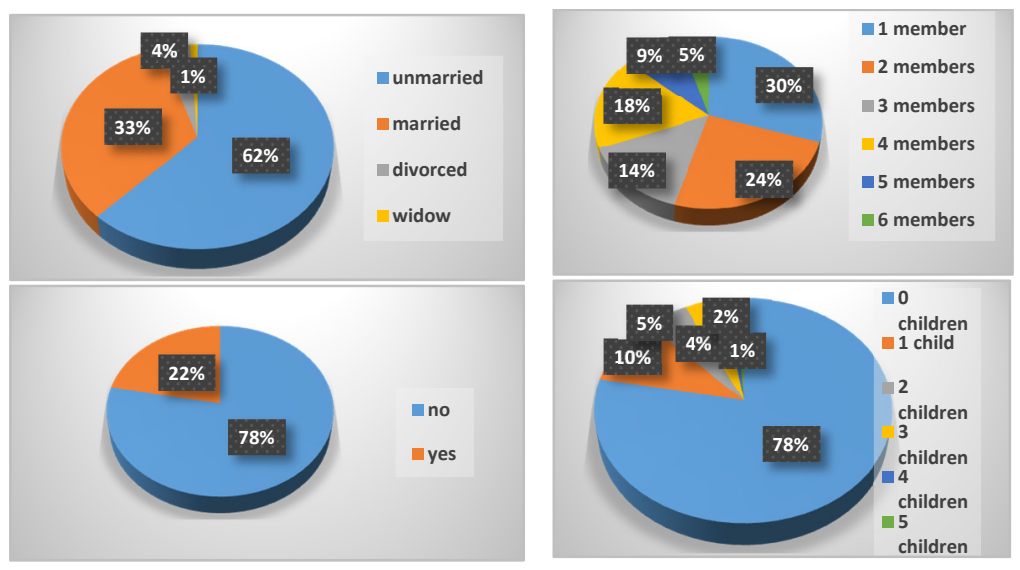

Fig. 3. Civil status (up-left); Number of members from family (up-right) Existence of children in family (down-left); Number of children in family (down-right)

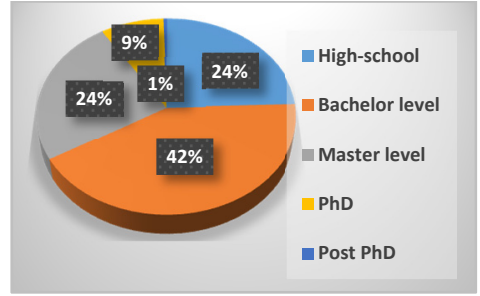

Fig. 4. Last graduated educational level
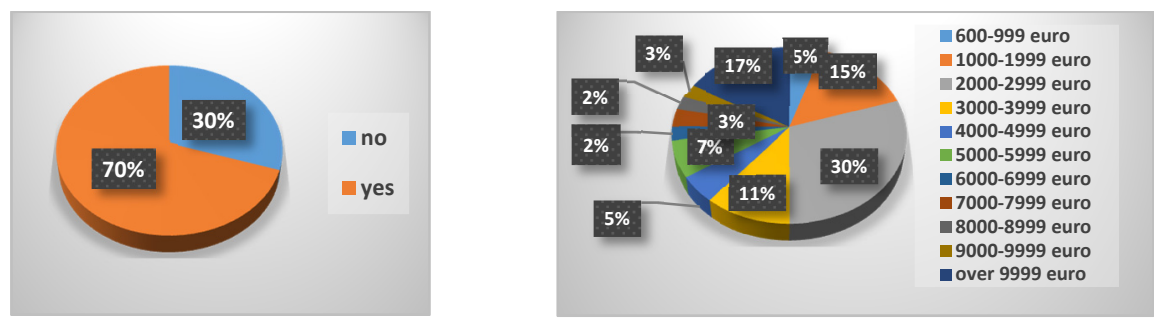

Fig. 5. Percentage of professionally active respondents (left),

Family monthly net income (right) 
Table. 1. Reasons to travel

About the motivation, for the actual research, the main purpose of the travel usually is visiting the tourism attractions and discovering the local lifestyle. Also, the reasons for which they usually travel are presented in the table, noticing that the most popular are the desire to spend the free time in another place and to visit another place and its tourist attractions. Also, according to the previous research, the top 3 main motivations were: leisure - 36\% attending festivals, concerts or other cultural events - $16 \%$ and personal reasons (meeting friend or relatives, health) - 16\% (Toader et al. 2015).

\begin{tabular}{|l|l|}
\hline Reasons to travel & Percentage \\
\hline $\begin{array}{l}\text { to escape from the daily } \\
\text { routine }\end{array}$ & $73.0 \%$ \\
\hline $\begin{array}{l}\text { To interact with people } \\
\text { from other places }\end{array}$ & $71.0 \%$ \\
\hline $\begin{array}{l}\text { To visit another place and } \\
\text { its touristic attractions }\end{array}$ & $56.5 \%$ \\
\hline $\begin{array}{l}\text { To fulfill responsabilities } \\
\text { from work }\end{array}$ & $55.0 \%$ \\
\hline $\begin{array}{l}\text { To attend events in } \\
\text { family/group of friends }\end{array}$ & $29.5 \%$ \\
\hline To visit family/friends & $20.5 \%$ \\
\hline To volunteer & $12.5 \%$ \\
\hline To participate In fairs & $11.0 \%$ \\
\hline $\begin{array}{l}\text { To attend } \\
\text { festivals/concerts }\end{array}$ & $10.0 \%$ \\
\hline To shop & $8.0 \%$ \\
\hline To cure health problems & $5.5 \%$ \\
\hline To relax & $4.0 \%$ \\
\hline To study & $2.0 \%$ \\
\hline
\end{tabular}

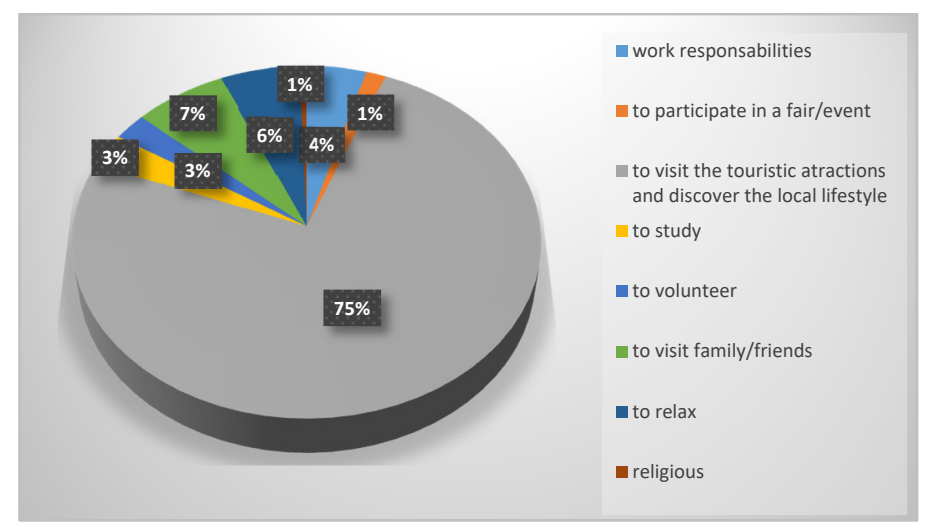

Fig. 6. Main reasons to travel

Related to the tourism circulation, according to the actual research, most of tourists usually travel more than 3 times/year, 22-60 days/year and the length of a travel is 7-8 days. 


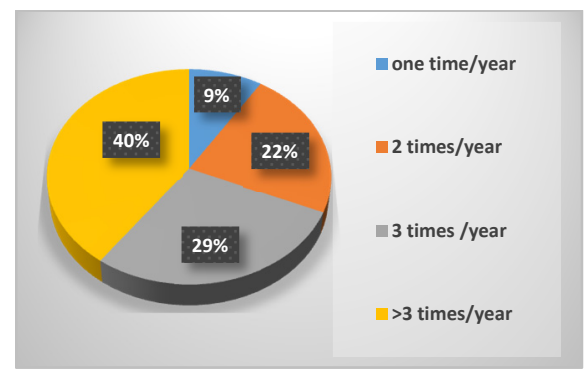

Fig. 7. Frequency of travels/year
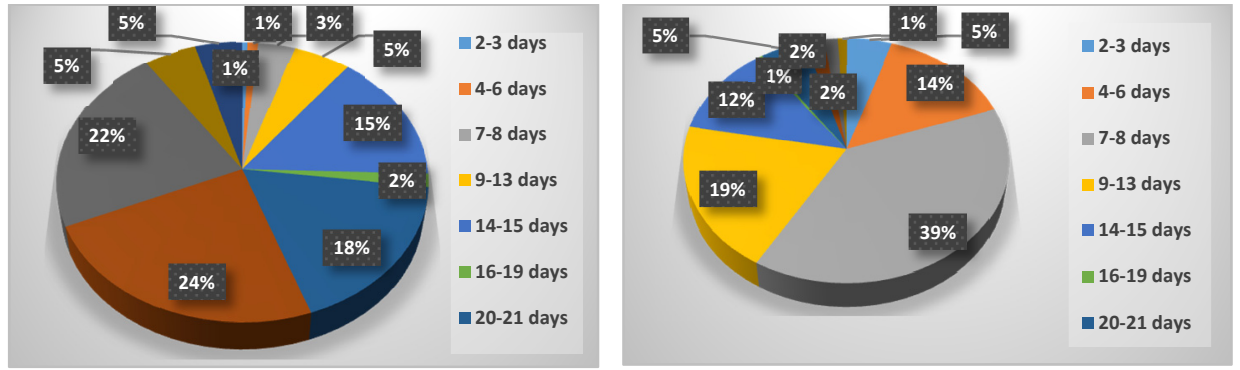

Fig. 8. Number of travel days/year (left); Length of one travel (right)

The previous research mentioned that most of the foreign tourists stayed for 2 nights - 16\%, over 7 nights - 14\%, only $9 \%$ deciding not to spend the night in this city. Over half of the foreign tourists have been in Cluj-Napoca before (57\%) and almost three quarters of them (71\%) at least 2 times/year (Toader et al, 2015).
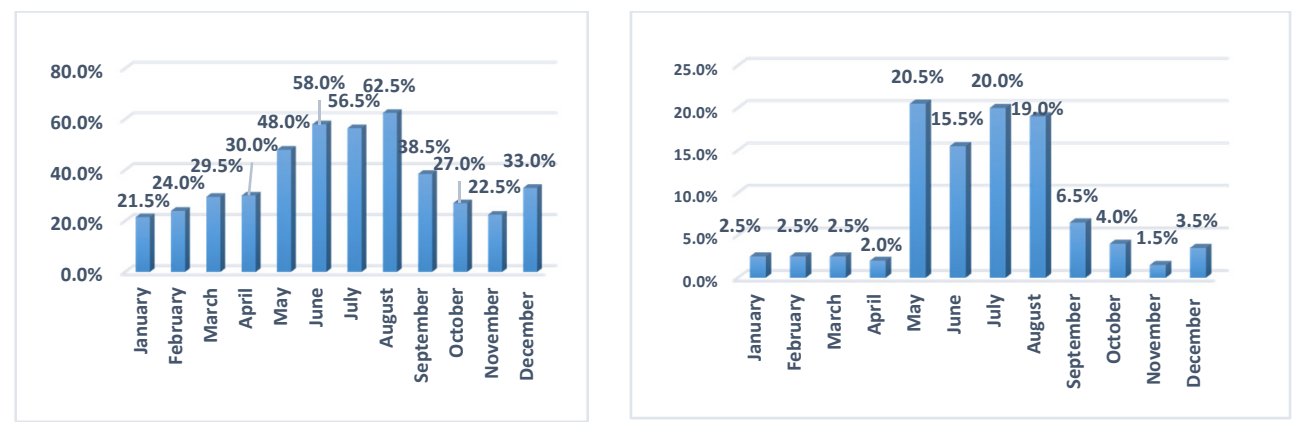

Fig. 9. The months they travel (left); The month they travel the most (right) 
Also, according to the present research, there is not a single month when foreign tourists travel the most. They travel predominantly in: May, June, July and August.
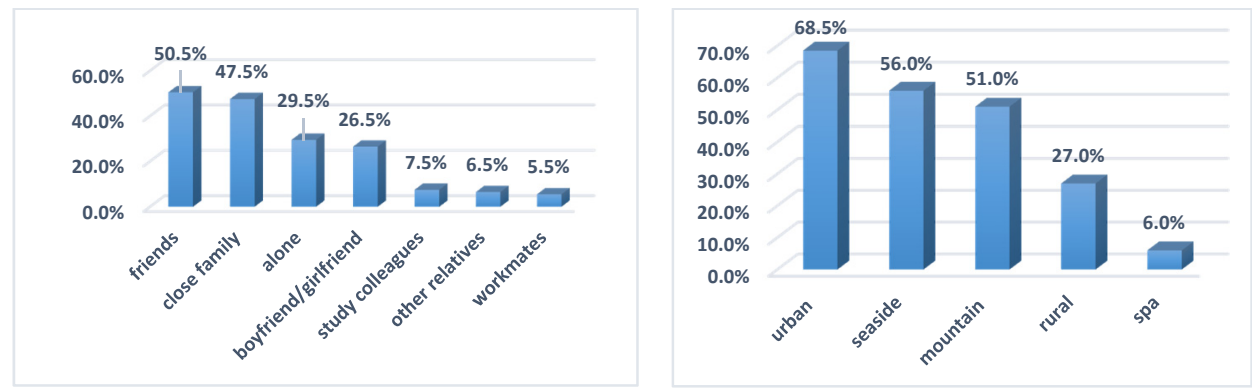

Fig. 10. Type of travel partners (left); Type of travel destination (right)

According to the present research, foreign tourists usually travel with friends $-50.5 \%$ and with the close family $-47.5 \%$, and, in general, they prefer urban (68.5\%), seaside (56\%) or mountain (51\%) destinations. According to the previous research, the size of a group traveling in Cluj-Napoca is of 3.4 persons (Toader et al, 2015).

In the following lines, we focus on the tourism packages and the services chosen.

According to the present research, foreign tourists generally opt for sejours - $58 \%$ and prefer to plan the trip without an intermediary, alone or with somebody else $-85 \%$.
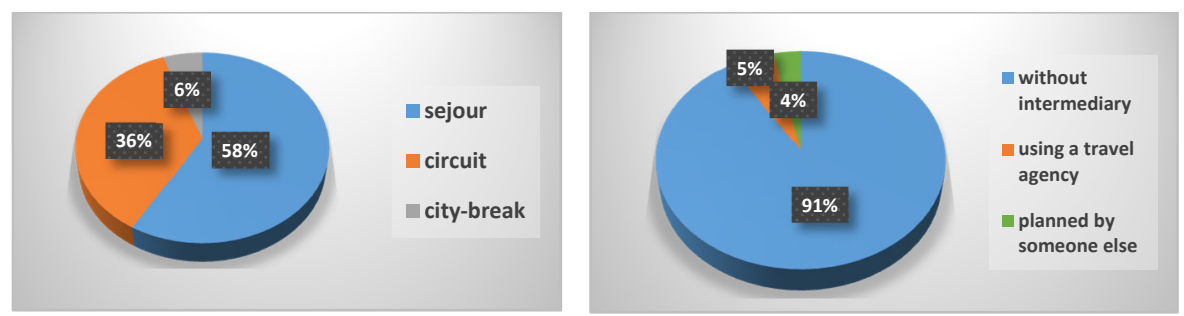

Fig. 11. Type of travel (left); Way of planning the travel (right) 
According to the previous research, the main means of transportation chosen to arrive in Cluj-Napoca are: the plane - $42 \%$, followed by car - $27 \%$ and bus - 18\% (Toader et al, 2015). The actual research confirms that fact, as it also resulted that most foreign visitors - over two thirds, use the plane most frequently.

Also, the previous research mentioned that within Cluj-Napoca, the respondents move primarily by walking (39.8\%), with taxi $(32.7 \%)$ or with means of urban transportation (Toader et al, 2015) and, according to the actual research, the majority of tourists use urban public transportation $(45.5 \%)$, followed by rented car (21.5\%) and personal car (18.5\%).

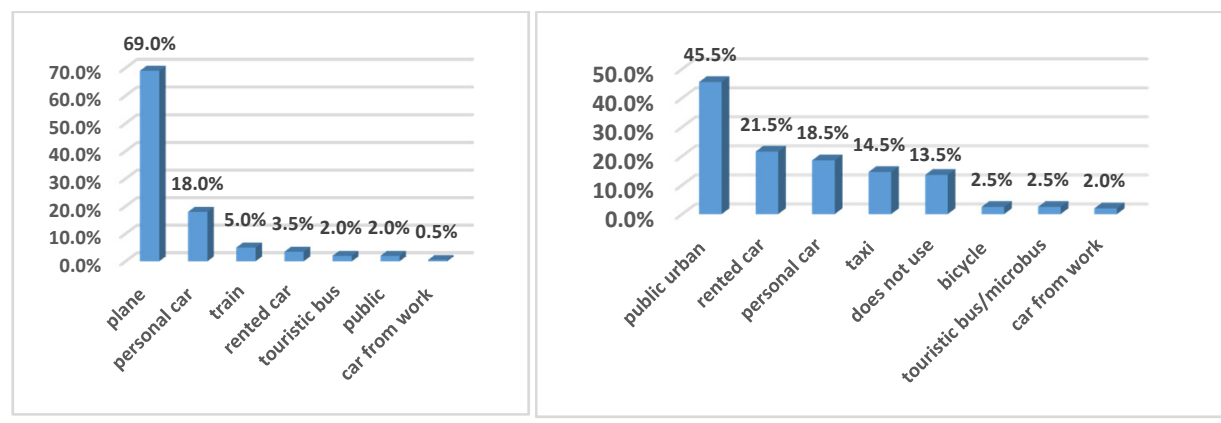

Fig. 12. Means of transportation to the destination (left); Means of transportation at the destination (right)

According to the present study, the respondents usually chose hotels (49\%), followed by hostels (23.5\%) and aparthotels (13\%). Also, in the previous research, most of the foreign tourists (70\%) chose accommodation units, 58\% - three-star units, on the second place being the four-star units 21\% (Toader et al, 2015).

Concerning the food services, the present research showed that, in general, tourists preferred only the breakfast to be included in the price of the accommodation - 55\%. These results reinforce the ones obtained in the previous research, where $55.6 \%$ chose to dine in another unit than the one in the accommodation unit (Toader et al., 2015).

Regarding the tour guide, the present research indicated that, in general, most of the tourists use tour guiding services, over half attend only free guided tours, the majority do not buy tourism packages from the travel agencies and, when achieved, tour guides are not included. 

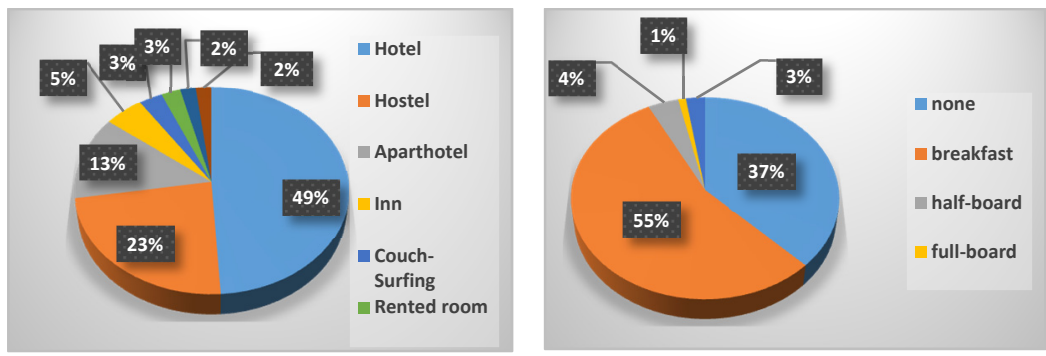

Fig. 13. Type of accommodation (left); meals included in the price of accommodation (right)
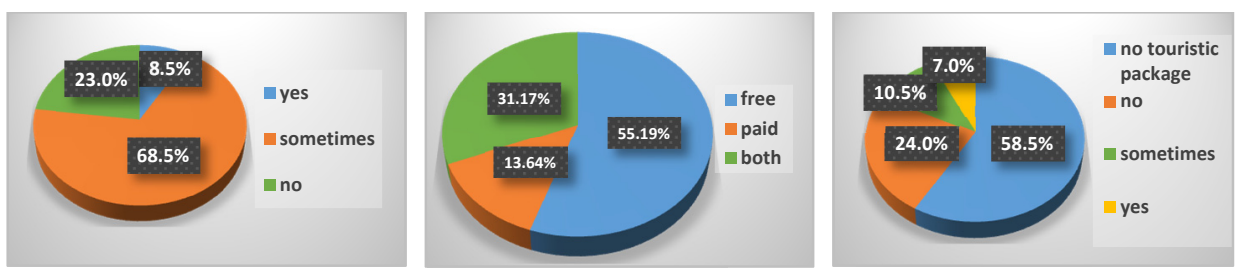

Fig. 14. The measure in which tourists opt for tour guide (left); type of guided tour (center), The measure in which the tour guide is included in the bought tourism packages (right)

According to the present research, during their travels, in general, foreign tourists perform various activities, mentioned in table 2. Cultural visits are preferred. Also, it resulted from the previous research that foreign tourists in Cluj-Napoca take part in guided tours and go on trips (Toader et al, 2015).

\section{CONCLUSIONS}

Using the results of the research, a possible profile of the foreign tourists visiting Cluj-Napoca was identified.

It resulted that these tourists live in urban areas, are 26-54 years old, unmarried, living alone or with another person,

Table 2. Types of activities

\begin{tabular}{|l|r|}
\hline Type of activity & Percentage \\
\hline Cultural visits & $86.5 \%$ \\
\hline $\begin{array}{l}\text { Spending time in } \\
\text { clubs/bars }\end{array}$ & $38.5 \%$ \\
\hline $\begin{array}{l}\text { Attending } \\
\text { cultural events }\end{array}$ & $37.0 \%$ \\
\hline Shopping & $35.5 \%$ \\
\hline $\begin{array}{l}\text { Participating in } \\
\text { guided tours }\end{array}$ & $31.0 \%$ \\
\hline $\begin{array}{l}\text { Participating in } \\
\text { trips }\end{array}$ & $27.5 \%$ \\
\hline $\begin{array}{l}\text { Participating in } \\
\text { musical events }\end{array}$ & $22.5 \%$ \\
\hline $\begin{array}{l}\text { Participating in } \\
\text { sportive events }\end{array}$ & $8.5 \%$ \\
\hline $\begin{array}{l}\text { Activities from } \\
\text { job }\end{array}$ & $4.5 \%$ \\
\hline Volunteering & $3.5 \%$ \\
\hline Studies \\
\hline Religious \\
\hline
\end{tabular}


without children, have graduated bachelor level, are professionally active, have a net monthly family income less than 2999 euro. The main purpose of the travel is to visit the tourism attractions and to discover the local lifestyle and the reasons to travel are to escape from the daily routine and to interact with people from other places. The tourists travel 22-60 days /year, more than 3 times/year, stays are 7-8 days long, usually between May and August, in urban, seaside or mountain destinations, with friends or close family. They arrive in Cluj-Napoca at least 2 times/year and the size of the travel group is 3.4 persons.

The sejours planned without intermediaries are preferred. The tourists arrive at the tourist destination with the plane and there they use the urban public transportation. In Cluj-Napoca they also use taxies. They prefer threestar hotels, with breakfast included in the price of the accommodation, sometimes they have tour guide, attending mostly free guided tours and perform cultural visits.

The limits of the research consist of the refusal of a significant number of tourists to provide information for the survey and, also, the limited amount of time available for the study. Thereby, for the following research, the questionnaire will be applied to a larger number of tourists for a longer period of time.

We are grateful to the following members of Cluj Guided Tours Association: Raluca Bolnavu, Anita Odobleja, Alexandra Selinceanu, Valentin Anghelescu, Cătălin Banea, Alexandru Bălășoiu, Edmund Mai and Alexandru Rotariu, for helping to apply the questionnaire. We also thank respondents to the survey for their patience and courtesy of answering the questions, providing essential help to realise this research.

The obtained information of this study is actual and useful for the tourism area. The research provides information related to the geographical features, socio-demographic attributes, and behavioural characteristics.

This article was designed to be a pilot study for a larger research.

\section{REFERENCES}

1. Becker, Elisa, Leisch, F., Dolnicar, Sara (2017), Visiting friends or relatives?, Tourism Management, vol.60, p. 56-64.

2. Benedek, J. (2006), Social Sustainability in the Historical District of Cluj, in Enyedi Gy., Kovacs, Z. (eds.) Social Changes and Social Sustainability in Historical Urban Centres. Centre for Regional Studies of Hungarian Academy of Sciences, Pécs, p.147- 161.

3. Benedek, J. (2010), Changes in Spatial Structure of Cluj-Napoca after 1989, Romanian Journal of Population Studies, (4): 1, p. 24-37. 
4. Bolog, Cristina, Mathe, A. (2015), Îmbinarea realului cu virtualul ca perspectivă pentru dezvoltarea turismului urban în Cluj-Napoca, Geographia Napocensis, XI, No. 2, p. 83-92.

5. Chang, Janet, (2006), Segmenting Tourists to aboriginal cultural festivals: An example in the Rukai tribal area, Taiwan, in Tourism Management, vol. 27, p. 12241234.

6. Cocean, P., Dezsi, Șt. (2009), Geografia Turismului, Edit. Presa Universitară Clujeană, Cluj-Napoca.

7. den Hoed, W., Russo, A.P. (2017), Professional travellers and tourist practices, Annals of Tourism Research, vol 63, p.60-72.

8. Jaapar, M., Musa, G., Moghavvemi, Sedigheh, Saub, R. (2017), Dental Tourism: Examining tourist profiles, motivation and satisfaction, Tourism Management, vol. 61, p.538-552.

9. Kim, H., Cheng, H.C., O’Leary, J.T. (2007), Understanding participation patterns and trends in tourism cultural attractions, Tourism Management, vol. 20, p. 1366-1371.

10. Lopez-Guzman, T., Vieira-Rodriguez, Aurea, Rodriguez-Garcia, J. (2014), Profile and motivation of European tourists on the Sherry wine route of Spain, Tourism Management Perspectives, vol. 11, p. 63-68.

11. Molera, Lourdes, Albaladejo, Isabel Pilar (2007), Profiling segments of tourists in rural areas of South Easthern Spain, Tourism Management, vol. 28, p.757-767.

12. Păcurar, Al. (2009), Turism internațional, Edit. Presa Universitară Clujeană, ClujNapoca.

13. Pinheiro Melo Borges Tiago, Maria Teresa, De Almeida, J.P., Gomes Borges Tiago F., Costa Dias Faria, Sandra Micaela (2016), Baby Boomers turning grey: European profiles, Tourism Management, vol. 54, p. 13-22.

14. Pop, Iuliana (2013), Profilul consumatorului de turism rural, Teză de doctorat, Universitatea Babeș-Bolyai Cluj-Napoca.

15. Prayag, G., Disegna Marta, Cohen S.A., Yang, (Gordon) H. (2015), Segmenting Markets by Bagged Clustering: Young Chinese Travelers to Western Europe, Journal of Travel Research, vol. 54(2), p. $234-250$.

16. Priporas, C.V., Vassiliadis, C.A., Bellou, Victoria, Andronikidis A. (2015), Exploring the Constraint Profile of Winter Sports Resort Tourist Segments, Journal of Travel Research, vol. 54, p.659-671.

17. Stănciulescu, Gabriela, State, Olimpia, (2013), Tehnica operațiunilor de turism intern și internațional, Edit. C. H. Beck, București.

18. Stepchenkova, Svetlana, Shichkova, Elena, Kim, H., Pennington-Gray, Lori, (2015), Segmenting the 'visiting friends and relatives' travel market to a large urban destination: the case of Nizhni Novgorod, Russia, Journal of Destination Marketing and Management, vol. 4, p.235-247.

19. Toader, V., Negrusa, Adina Letiția, Cosma, Smaranda, Bolog, Cristina (2015), Cultural tourist's behavior - Case study foreign tourists in Cluj-Napoca, Proceedings of the International Conference SCience in TEchnology - ScinTE-2015, p. 34-37.

20. www.insse.ro

21. http://www.clujnapoca2021.ro/proiecte/aplicatie-cluj-napoca-2021.html 